\title{
Study on the Creep Characteristics of Sandstone under Coupled Stress-water Pressure
}

\author{
Zuosen Luo ${ }^{1,2}$, Jianlin Li ${ }^{1,2}$, Lehua Wang ${ }^{1,2}$, Eleyas Assefa ${ }^{3}$, Huafeng Deng ${ }^{1,2^{*}}$ \\ 1 Collaborative Innovation Center for Geo-Hazards and Eco-Environment in Three Gorges Area, 443002, Yichang, Hubei, China \\ 2 Key Laboratory of Geological Hazards on Three Gorges Reservoir Area, China Three Gorges University, Ministry of Education, \\ 443002, Yichang, Hubei, China \\ ${ }^{3}$ College of Architecture and Civil Engineering, Addis Ababa Science and Technology University, 1000, Addis Ababa, Ethiopia \\ * Corresponding author, e-mail: dhf8010@ctgu.edu.cn
}

Received: 18 July 2019, Accepted: 26 September 2019, Published online: 24 October 2019

\begin{abstract}
Long-term interaction between stress and water pressure leads to creep damage of reservoir bank slope. As a result there will be instability of the bank slopes in many water conservancy projects. The rock mass creeping effect of coupled stress-water pressure was studied by using a typical sandstone rock from the Three Gorges reservoir area. The experiment was conducted by using the rock immersion-air-drying cyclic load rheometer device (designed and manufactured by our research team). Based on the experimental results, the following key points were observed: 1) the creep strain and the steady-state creep rate was increasing when the water pressure increased (at the same stress level). Under the same water pressure, the increase in the axial pressure resulted in the increase in the creep strain and steady creep rate of the sandstone specimens. 2) the increase in the axial pressure increased the creep strain and steady-state creep rate of the sandstone specimens while the water pressure increased. The mechanical properties of the sandstone specimens were affected by the water pressure. 3) the water infiltrates through the pore surfaces. As a result, the rate of deformation will increase while the bearing capacity and long-term strength of the rock decrease. This paper provides a solid theoretical foundation for the evaluation and prediction of reservoir geological hazards.
\end{abstract}

Keywords

rock mechanics, sandstone, creep, water pressure

\section{Introduction}

New reservoir banks develop due to the construction of some large-scale water conservancy and hydropower projects. However, the deformation and failure of the bank slopes need a proper solution. According to statistics, there are many reservoir landslides and failures. Water-rock interaction has a significant effect on the stability of bank slope. The mechanical properties of rock under dry and saturated conditions are different. Dyke and Dobereiner [1], Hawkins and McConnell [2], and Chang and Haimson [3] studied the compressive strength of various sandstones and quartz sandstones under dry and saturated conditions. Based on the experimental findings, rocks lose their strength under saturated conditions. Vásárhelyi [4-6] introduced a method used for estimating the sensitivity of sandstone rocks to water content, based on published data. Liu et al. [7], Xu et al. [8], and Tang et al. [9] carried out a series of shear tests on different types of rocks together with structural planes and different water contents. The water content has a significant effect on the shear resistance of rock and structural surfaces. Many researchers studied the change in the rock properties under short-term or long-term immersion in an aqueous or chemical solution. Chigira and Oyama [10] studied the failure mechanism of mudstone and sandstone under coupled hydro-mechano-chemical process. Sausse et al. [11] studied the influence of mineral deposition and dissolution on the permeability of rock joint surface. Polak [12] investigated the permeability of fractured rock under chemical action and established a mathematical relationship between the geometric parameters of fracture and fluid properties. Feng and Ding [13] studied the dynamic propagation process and development of cracks under the action of water chemistry. Fantong et al. [14] analyzed the long-term stability of the Lake Nyos dam with the consideration of water-rock chemistry. 
With the actual short-to-long term requirements of early warning and monitoring systems of geological disasters, investigating the effect of water on the rock mass properties is very important. It is the conventional deterioration law for the physical and mechanical properties of rocks. Moreover, it is used to understand the rheological characteristics of the rock under a long term water-rock interaction. At present, the effect of water on the creep characteristics of rock gets wide attention. Parkin [15], Jin and Cristescu [16], Kenis et al. [17], Gasc-Barbier et al. [18], Wang et al. [19], $\mathrm{Xu}$ et al. [20], Yang et al. [21], and others conducted rheological tests on rocks such as mudstone. Shen et al. [22] performed an experimental study on the rheological properties of granite and carbonaceous shale under dry and saturated conditions. After saturation, the long-term strength of rock was reduced significantly. However, the rate of rheological deformation increased dramatically. Liu et al. [23] completed a series of uniaxial compression creep tests on sandstone specimens with dry, saturated, different ion concentration, and $\mathrm{pH}$ solution circulation. The results show that the creep properties of saturated sandstones are more prominent than dry sandstone. The creep properties of sandstone with different aqueous solutions were more noticeable than that of dry and saturated sandstone. Yao [24] conducted triaxial creep tests on coarse sandstone under different water content conditions. The higher the water content of the rock, the higher the instantaneous strain, the higher the creep rate, and the lower the long-term strength. A linear relationship was observed between the instantaneous strain and the water content. However, the long-term strength and water content had a logarithmic relation. Ju et al. [25] studied the creep properties of red mudstone under different water conditions. The ratio between creep strain and instantaneous strain increased with the increase of water content. However, the long-term strength was decreasing while the acceleration creep rate increased.

Creep damage on the bank slope occurs as a result of longterm stress and water pressure. The bank slope rock mass is often subjected to stress and is also in direct contact with the reservoir water. In the past, conventional experiments often neglect the direct effect of water, and could not accurately simulate the creep mechanical properties of rocks in the real reservoir water environment. A sandstone rock from the Three Gorges reservoir area was used to simulate a practical geotechnical creep problem. The rock immersion-air-drying cyclic load rheometer (designed and manufactured by our research team) was used to study the long-term creep characteristics of sandstone under coupled stress-water pressure.

\section{Experimental program}

\subsection{Sample preparation}

A typical sandstone rock from the Three Gorges reservoir area was used to meet the objectives of this research. The rock specimens were prepared with a diameter of $50 \mathrm{~mm}$ and a height of $100 \mathrm{~mm}$. The discrepancy in the diameter and height of the prepared sample is within $0.3 \mathrm{~mm}$. Accordingly, the unevenness of the bottom and top of the sample is less than $0.05 \mathrm{~mm}$.

For uniformity, the specimens with defects (such as cracks, visible joints, impurities, etc.) were rejected. Besides, the specimens were subjected to ultrasonic longitudinal wave test [26]. Samples were screened to avoid any defect. Selected samples are shown in Fig. 1. The density ranges between $2.51 \mathrm{~g} / \mathrm{cm}^{3}$ and $2.64 \mathrm{~g} / \mathrm{cm}^{3}$, and the longitudinal wave velocities were between $3860 \mathrm{~m} / \mathrm{s}$ and $4180 \mathrm{~m} / \mathrm{s}$.

\subsection{Testing apparatus}

Parts of the bank slope have been in contact with the reservoir water and subjected to pressure (Fig. 2).

As shown in Fig. 3, the coupled effect of stress and water pressure on the rock specimen was simulated by using the "YRQ-1000 rock immersion-air drying cycle load rheometer" (developed by our research team). The applied force diagram on the rock specimen is shown in Fig. 4.

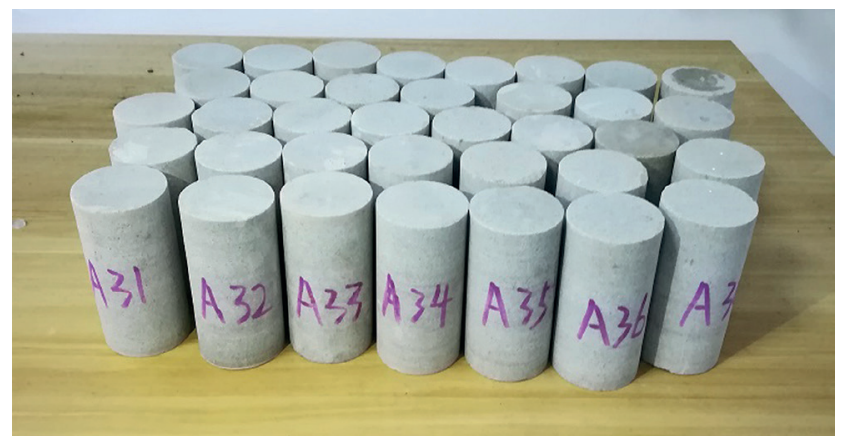

Fig. 1 Typical rock samples

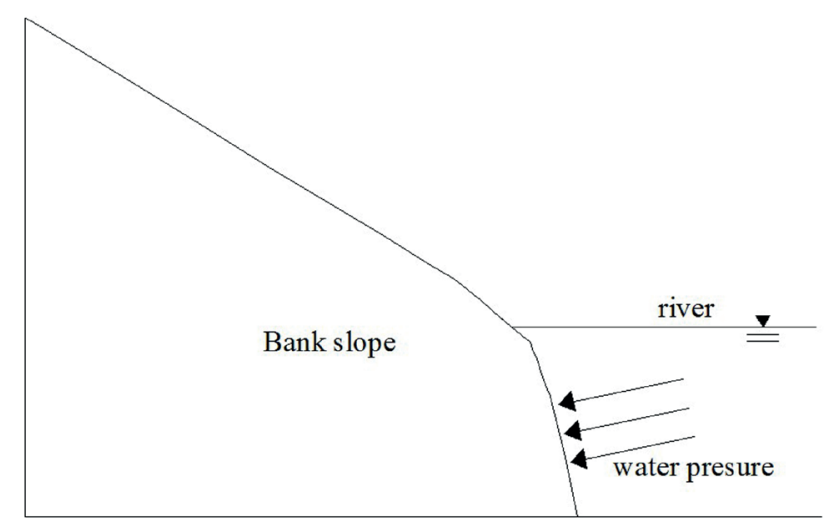

Fig. 2 Schematic diagram of the reservoir water and the bank slope 


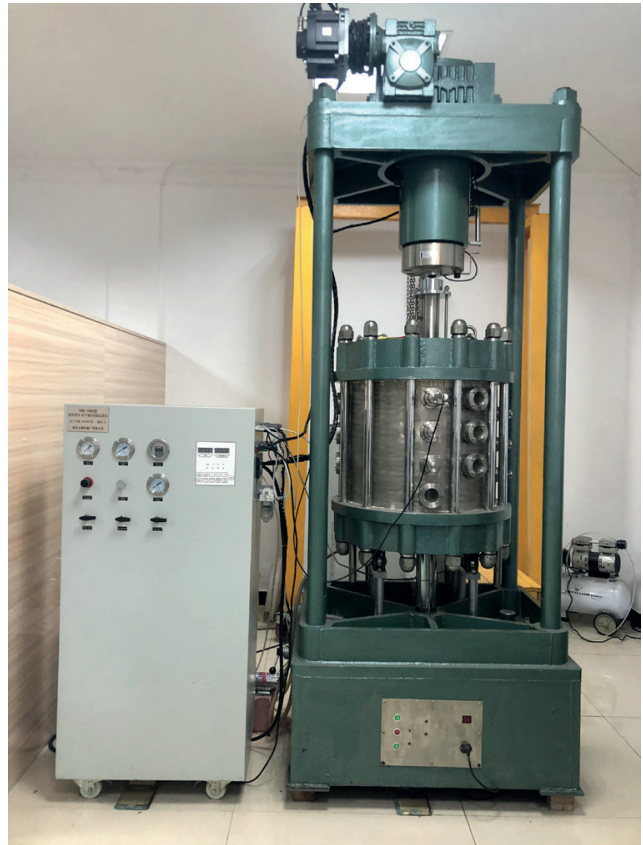

Fig. 3 YRQ-1000 rock soaking-air drying cycle load rheometer

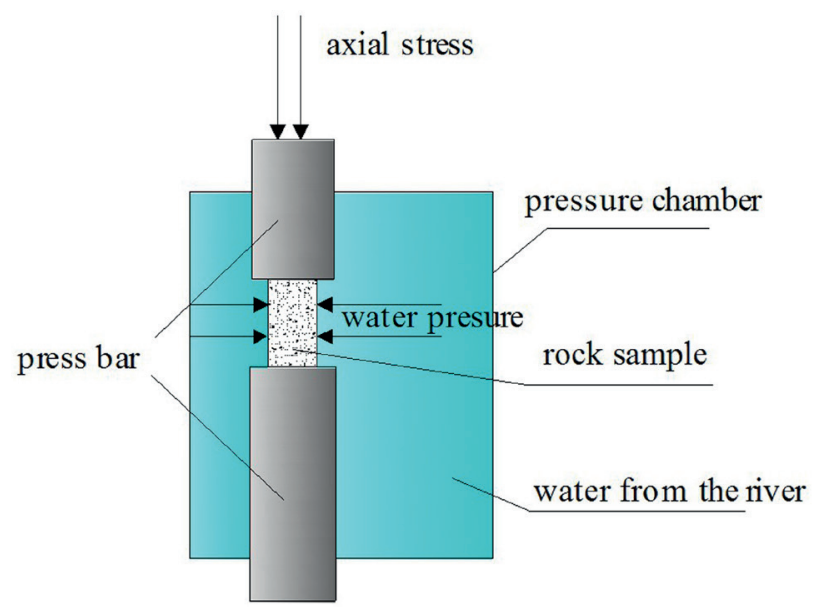

Fig. 4 The force diagram of the test specimen

The whole testing process was controlled by the computer. The test results were automatically stored in the computer and exported to an Excel file.

\subsection{Test scheme}

At first, the selected rock samples were vacuumed and immersed in the water at room temperature for about 48 hours to achieve full saturation. The designed water pressures were $0,0.5 \mathrm{MPa}, 1.0 \mathrm{MPa}, 1.5 \mathrm{MPa}$, and $2.0 \mathrm{MPa}$, respectively, simulating the effect of $50 \mathrm{~m}, 100 \mathrm{~m}, 150 \mathrm{~m}$, and $200 \mathrm{~m}$ water heads. The multi-stage axial stress was applied to the sample, and the initial axial stress was about $60 \%$ of the ultimate compressive strength. The axial loading process is shown in Table 1.
Table 1 Creep test loading scheme

\begin{tabular}{cccccc}
\hline $\begin{array}{c}\text { Water } \\
\text { pressure / } \\
\mathrm{MPa}\end{array}$ & First step & $\begin{array}{c}\text { Second } \\
\text { step }\end{array}$ & $\begin{array}{c}\text { Third } \\
\text { step }\end{array}$ & $\begin{array}{c}\text { Fourth } \\
\text { step }\end{array}$ & $\begin{array}{c}\text { Fifth } \\
\text { step }\end{array}$ \\
\hline 0 & 40 & 50 & 60 & 65 & 70 \\
0.5 & 40 & 50 & 60 & 65 & - \\
1.0 & 40 & 50 & 55 & 60 & - \\
1.5 & 40 & 50 & 55 & 57.5 & - \\
2.0 & 40 & 45 & 50 & 55 & - \\
\hline
\end{tabular}

\section{Test results}

The creep curves were established based on the superposition principle. Fig. 5 shows the axial, lateral, deviatoric, and spherical strains with different conditions. The numbers on the curve indicate the axial pressure values of each level.

Fig. 5 shows the strain-time curve of saturated sandstone at $0,0.5 \mathrm{MPa}, 1.0 \mathrm{MPa}, 1.5 \mathrm{MPa}$, and $2.0 \mathrm{MPa}$ water pressures. The creep curve of sandstone under coupled stress-water pressure has the following characteristics (Fig. 5): Sandstone shows noticeable creep and instantaneous strain characteristics under different stress levels. When the stress level is lower than the yield stress, the sandstone sample only undergoes to attenuating creep and steady-state creep. The final level of stress is higher than the yield stress. This stage not only has the characteristics of attenuating creep and steady-state creep but also exhibits accelerated creep characteristics.

\section{Analysis of test results}

\subsection{Analysis of creep deformation characteristics}

The effects of axial stress and water pressure on the creep deformation characteristics of sandstone were investigated. The cumulative total strain (including transient strain and creep strain) with the axial stress under different water pressures were plotted in Fig. 6 and Fig. 7 (The figures exhibit the axial, deviatoric, spherical, and lateral strains).

The relationships between total strain, axial stress, and water pressure are shown in Fig. 6:

1. When the water pressure is constant, the total strain increases with the increase in the axial stress; as the axial stress increases, the slope of the curve also increases, indicating that the axial stress is higher, the higher the change in strain.

2. When the axial stress is constant, the total strain increases with the rise in water pressure; and as the water pressure goes up, the total strain increases continuously, indicating that the water pressure is high. 


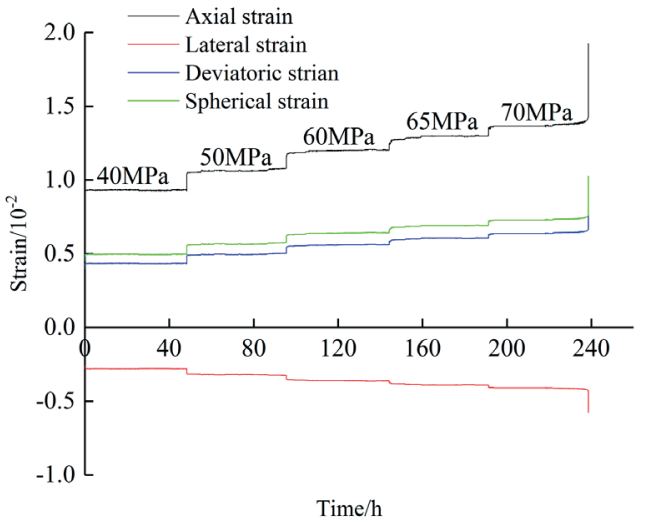

(a)

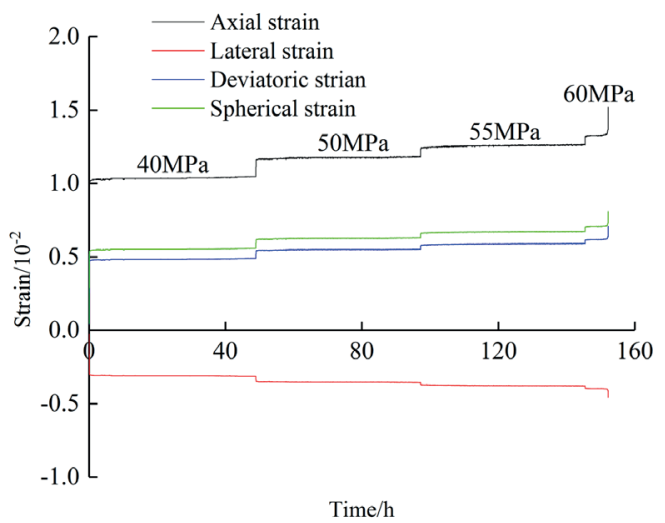

(c)

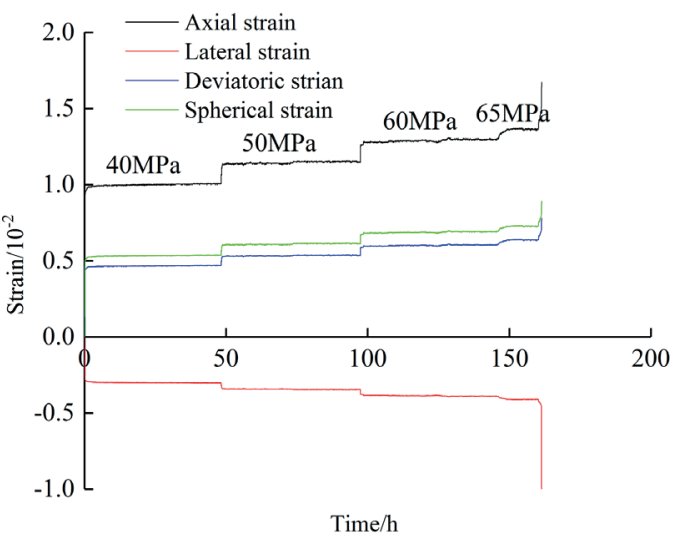

(b)

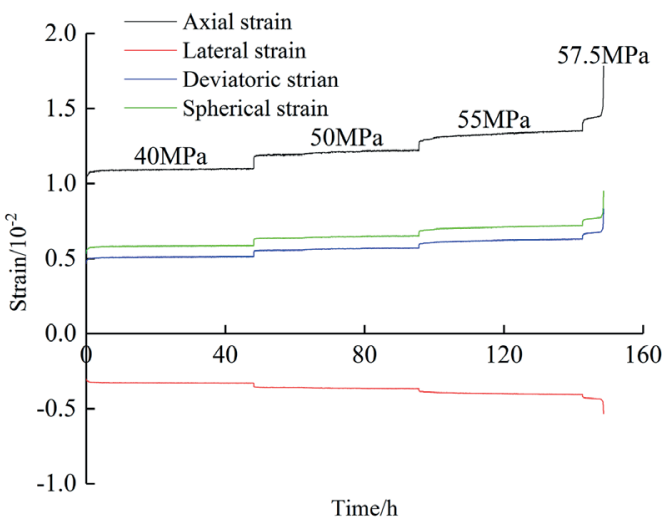

(d)

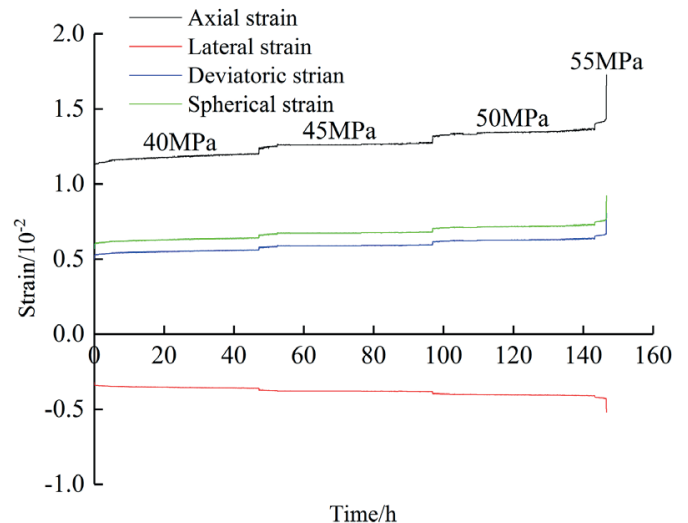

(e)

Fig. 5 Strain-time curve of sandstone rock under different water pressures; (a) 0MPawater pressure; (b) 0.5MPawater pressure; (c) 1.0MPawater pressure; (d) 1.5MPawater pressure; (e) 2.0MPawater pressure

The relationships between the creep strain, axial stress, and water pressure are shown in Fig. 7:

1. When the water pressure is constant, the creep strain increases linearly with the increase in the axial pressure; the creep strain varies with the axial pressure under different water pressures, and the creep increases with the increase in the water pressure. The increase in the strain with the increase in the axial stress is more pronounced.
2. When the axial stress is constant, the creep strain increases with the increase in the water pressure and axial stress; the creep strain is significantly affected by the water pressure.

In summary, axial stress and water pressure have a considerable impact on the creep deformation characteristics of sandstone specimens. Under high water pressure, the increase in axial stress has a more significant effect on the creep deformation characteristics. The reasons are 

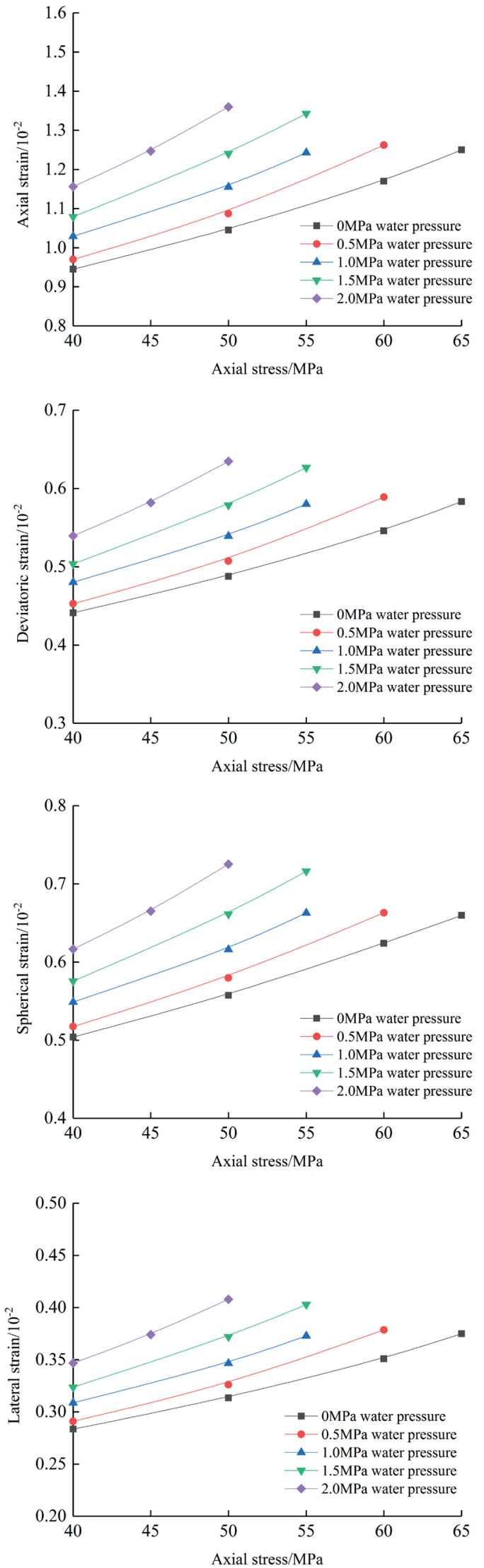

Fig. 6 Cumulative strain and axial stress under different water pressures
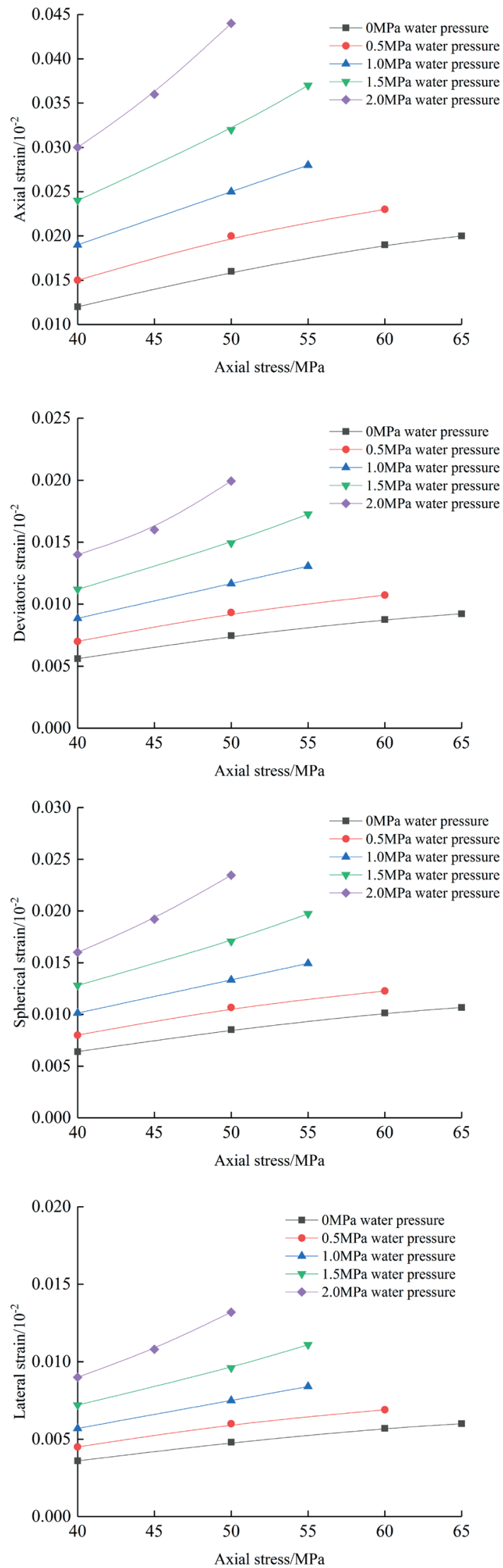

Fig. 7 Creep strain and axial stress under different water pressures 
mainly due to the gradual increase in axial stress, cumulative damage, and micro-cracks. Some micro-cracks will also form macro cracks. The cracks propagate due to the increase in the water pressure and axial stress. Infiltrated water through microcracks establishes continuous degradation. Therefore the effect of coupled stress water pressure on the creep deformation characteristics is very high.

\subsection{Analysis of creep rate}

The slope of the strain versus time curve is the creep rate. The creep rate at different durations can be determined.

The creep rate of sandstone was calculated at $40 \mathrm{MPa}$ stress level. The creep rate of the specimens at $0 \mathrm{MPa}$, 0.5 $\mathrm{MPa}, 1.0 \mathrm{MPa}, 1.5 \mathrm{MPa}$, and 2.0 $\mathrm{MPa}$ water pressure is shown in Fig. 8.

As can be seen from Fig. 8, the water pressure has a significant effect on the steady-state creep rate of the sandstone sample. As the water pressure increases, the decaying and steady-state creep increase. The axial steady-state creep
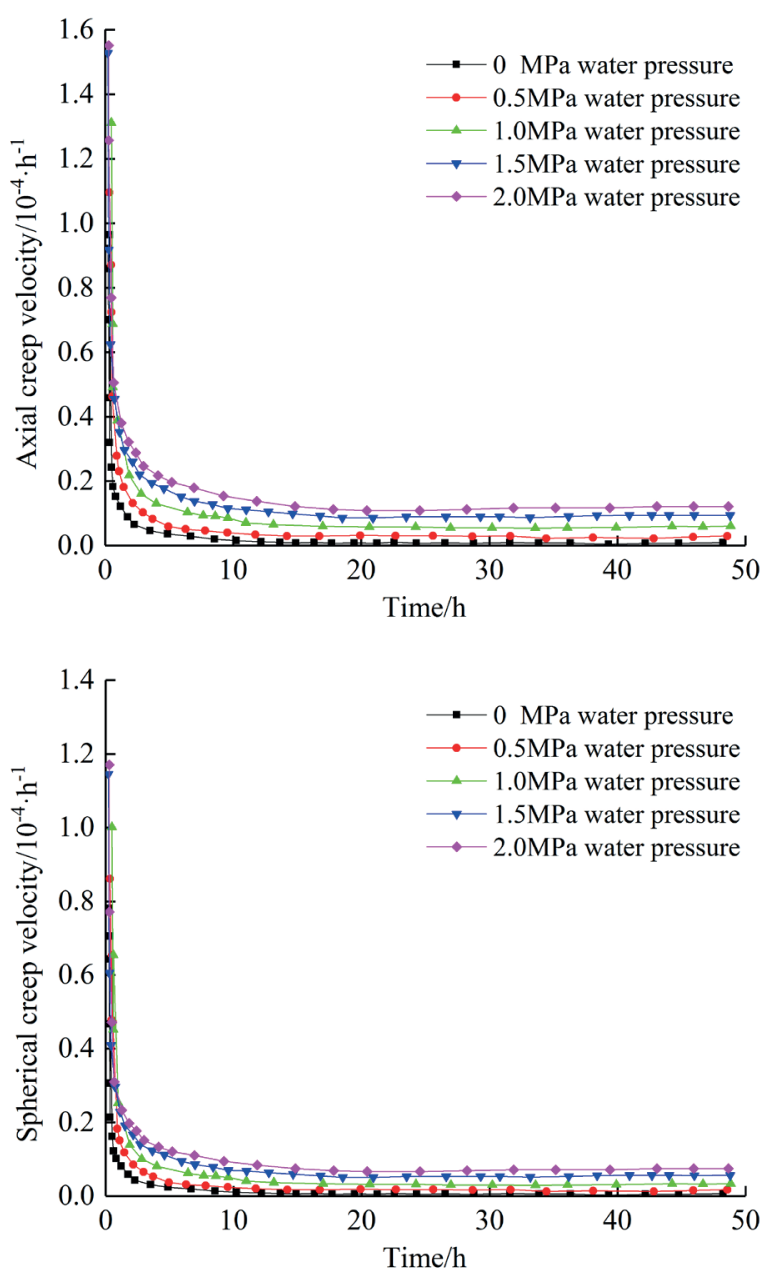

rates at $0 \mathrm{MPa}, 0.5 \mathrm{MPa}, 1.0 \mathrm{MPa}, 0.5 \mathrm{MPa}$, and 2.0 $\mathrm{MPa}$ water pressure are $0.9 \times 10^{-6} / \mathrm{h}, 2.2 \times 10^{-6} / \mathrm{h}, 5.8 \times 10^{-6} / \mathrm{h}$, $9.0 \times 10^{-6} / \mathrm{h}$, and $12.1 \times 10^{-6} / \mathrm{h}$, respectively, the deviatoric steady-state creep rates are $0.3 \times 10^{-6} / \mathrm{h}, 1.1 \times 10^{-6} / \mathrm{h}, 2.5 \times 10^{-6} /$ h, $3.6 \times 10^{-6} / \mathrm{h}$, and $4.6 \times 10^{-6} / \mathrm{h}$, respectively, the spherical steady-state creep rates are $0.6 \times 10^{-6} / \mathrm{h}, 1.7 \times 10^{-6} / \mathrm{h}$, $3.1 \times 10^{-6} / \mathrm{h}, 5.3 \times 10^{-6} / \mathrm{h}$, and $7.2 \times 10^{-6} / \mathrm{h}$, respectively, the lateral steady-state creep rates are $0.35 \times 10^{-6} / \mathrm{h}, 0.9 \times 10^{-6} / \mathrm{h}$, $1.9 \times 10^{-6} / \mathrm{h}, 3.3 \times 10^{-6} / \mathrm{h}$, and $4.7 \times 10^{-6} / \mathrm{h}$, respectively. The higher the water pressure has a considerable creep.

Similarly, the creep rate of sandstone samples at 2.0 $\mathrm{MPa}$ water pressure was calculated. The creep rates under $40 \mathrm{MPa}, 45 \mathrm{MPa}$, and $50 \mathrm{MPa}$ axial stress and $2 \mathrm{MPa}$ water pressure, are shown in Fig. 9.

As can be seen from Fig. 9, the axial pressure has a noticeable effect on the steady-state creep rate of the sandstone sample. As the axial stress increases, the steadystate creep increases. At $40 \mathrm{KN}, 45 \mathrm{KN}$, and $50 \mathrm{KN}$ axial stress, the axial steady-state creep rates are $12.1 \times 10^{-6} / \mathrm{h}$,
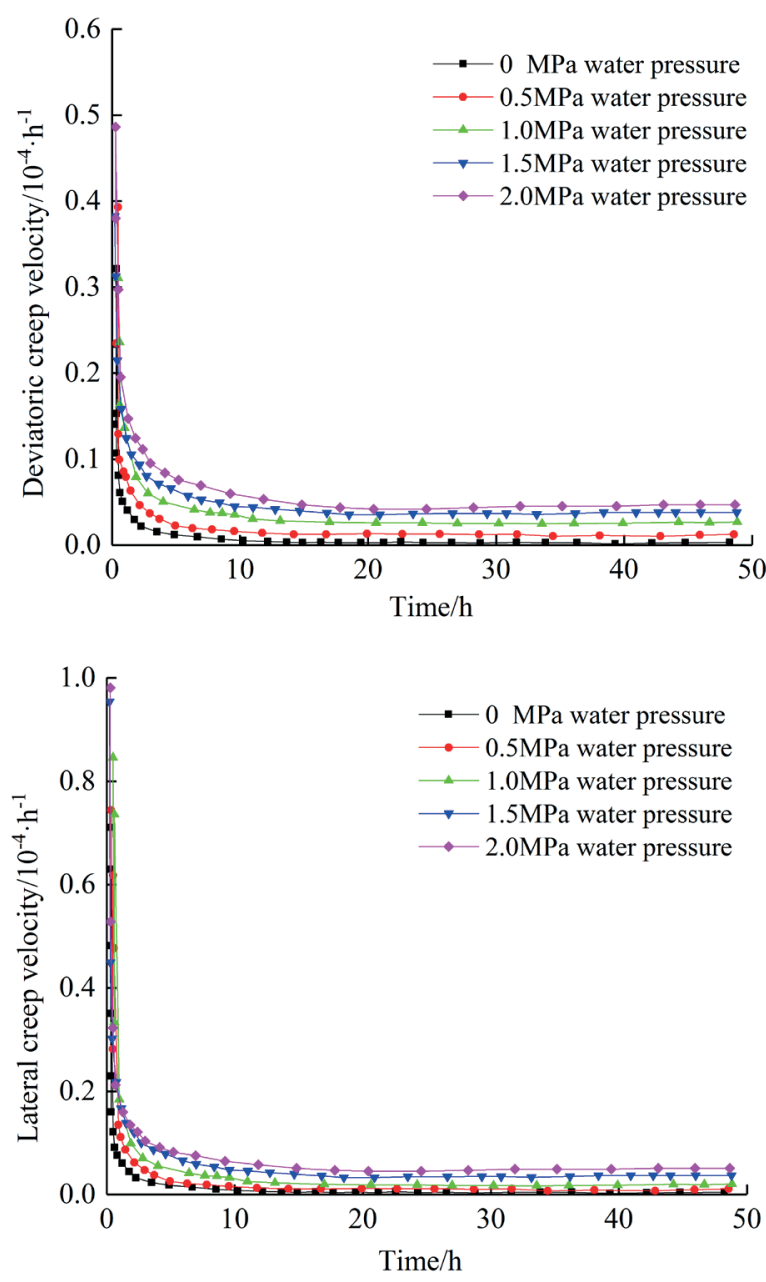

Fig. 8 Creep rate at 40MPa stress level 

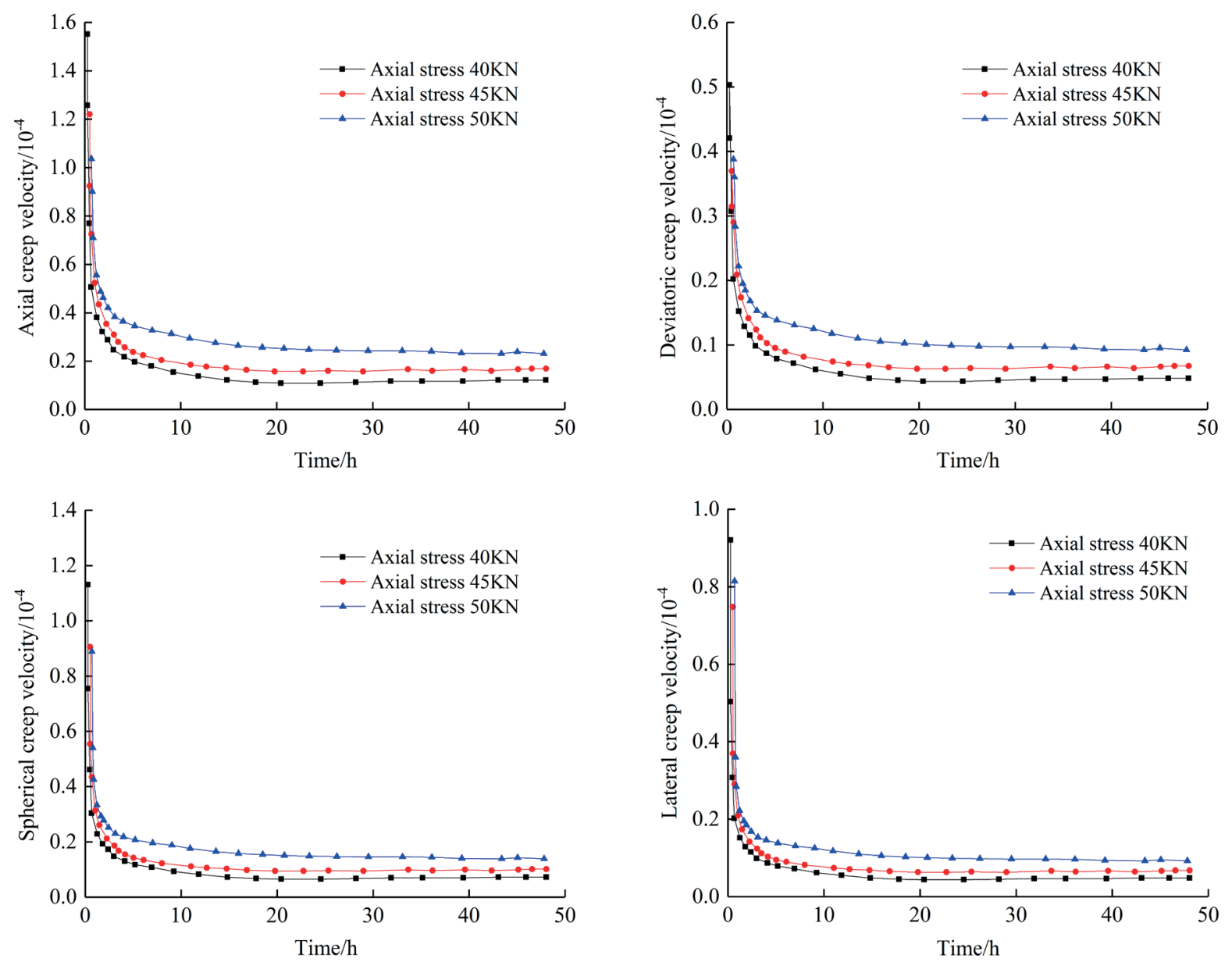

Fig. 9 Creep rate at $2 \mathrm{MPa}$ water pressure

$16.2 \times 10^{-6} / \mathrm{h}$, and $23.9 \times 10^{-6} / \mathrm{h}$, respectively. The deviatoric steady-state creep rates are $4.6 \times 10^{-6} / \mathrm{h}, 6.5 \times 10^{-6} / \mathrm{h}$, and $9.4 \times 10^{-6} / \mathrm{h}$, respectively. The spherical steady-state creep rates are $7.1 \times 10^{-6} / \mathrm{h}, 9.8 \times 10^{-6} / \mathrm{h}$, and $14.4 \times 10^{-6} / \mathrm{h}$, respectively. The lateral steady-state creep rates are $4.7 \times 10^{-6} / \mathrm{h}$, $6.6 \times 10^{-6} / \mathrm{h}$, and $9.1 \times 10^{-6} / \mathrm{h}$, respectively. The higher the water pressure is, the higher in the creep damage.

In general, the magnitude of axial stress controls the extent of internal cracks. The magnitude of water pressure governs the specimen's pore water pressure and the degree of crack propagation. The combination of the two determines the modification rate of the internal structure, the process of crack initiation and propagation, the creep rate, and the duration of decaying creep.

\subsection{Analysis of accelerated creep phase}

Sandstone specimens are failed at failure stress level. The strain and strain rate curves are shown in Fig. 10.

The sandstone samples have the same creep failure at different water pressures. They have shown attenuating creep stage, steady-state creep stage, and accelerated creep stage. The sample was creeping within the accelerated creep stage. The decaying and accelerated creep stages have a shorter duration. However, the isokinetic creep stage lasts longer.

For each stage, the failure of specimens was different. The creep duration of sandstone sample at failure stress level is shown in Table 2.

As the water pressure increases, the creep has the following trends: The proportion of total duration for decaying and accelerated creep was gradually increased. Similarly, the proportion of the total duration for steadystate creep has been gradually reduced. With the increase in the water pressure, the proportion of attenuation creep stage is $13.56 \%, 16.23 \%, 18.10 \%$, and $20.09 \%$ at $0 \mathrm{MPa}$, $0.5 \mathrm{MPa}, 1.0 \mathrm{MPa}$, and $2.0 \mathrm{MPa}$ pressure, respectively. The total duration of the accelerated creep phase showed an increasing trend $(7.03 \%, 8.04 \%, 9.97 \%$, and $12.02 \%)$. The proportion of the decaying and accelerated creep phase was increasing slightly while the water pressure increased. However, the proportion of steady-state creep dropped gradually. 

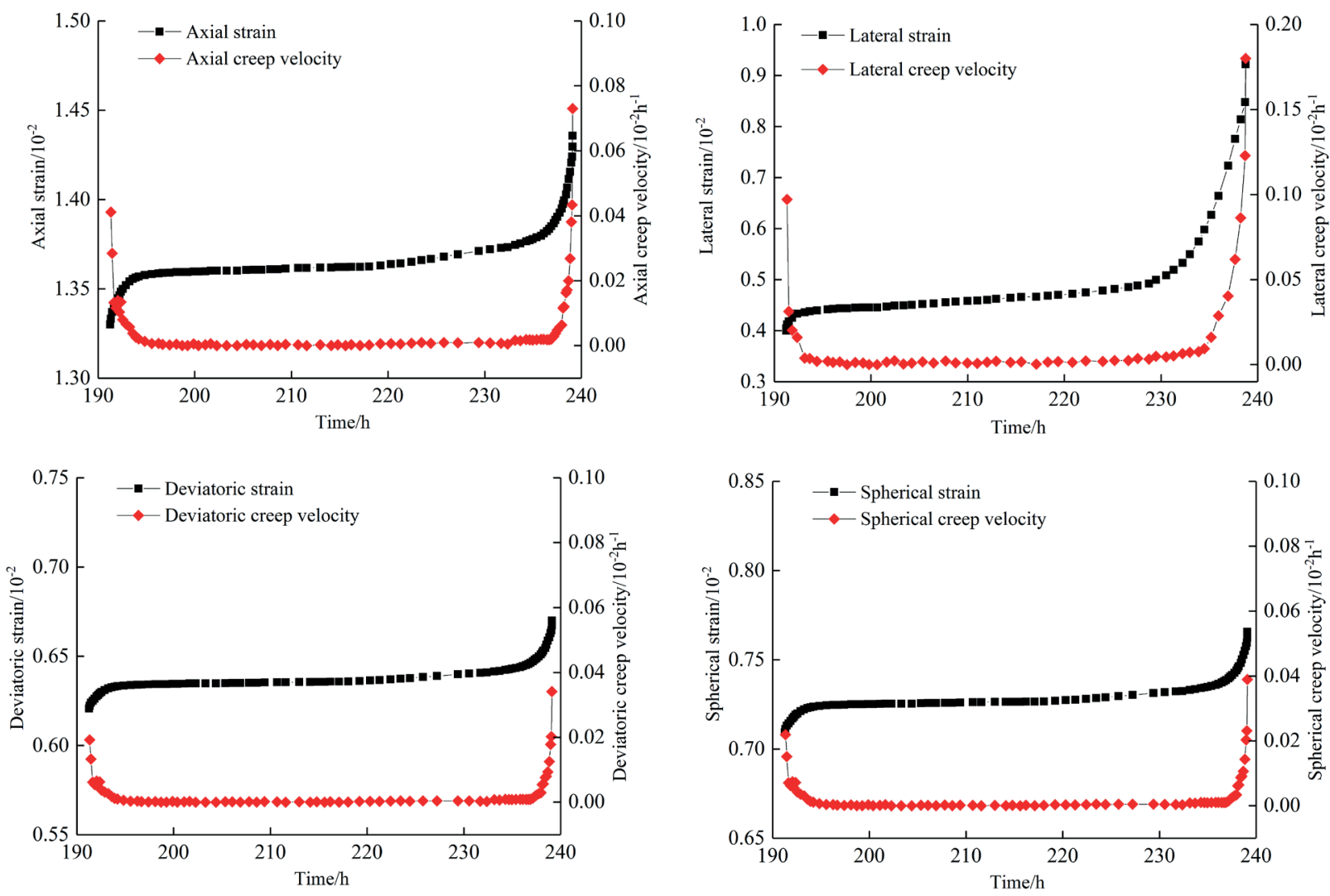

(a)
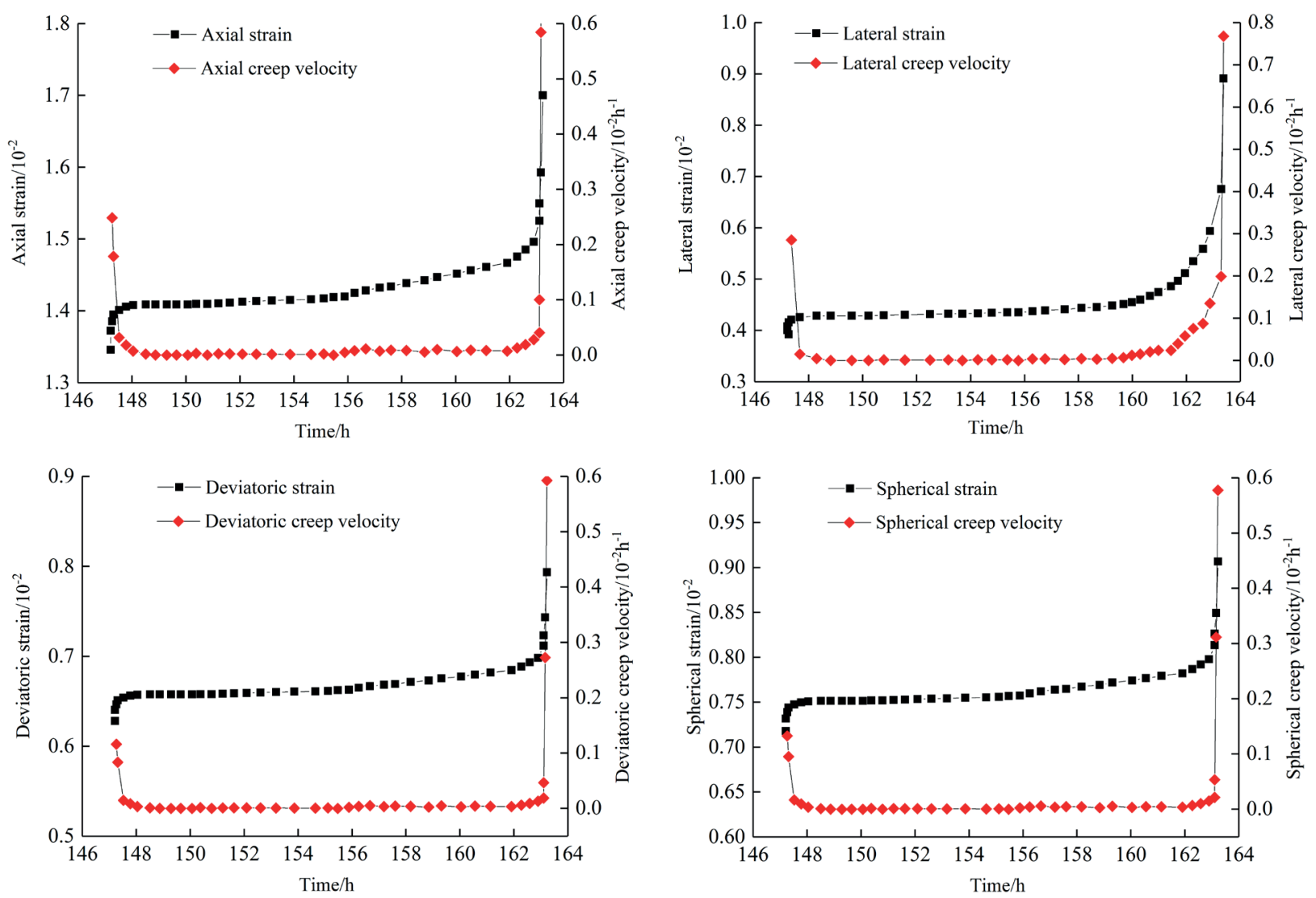

(b) 

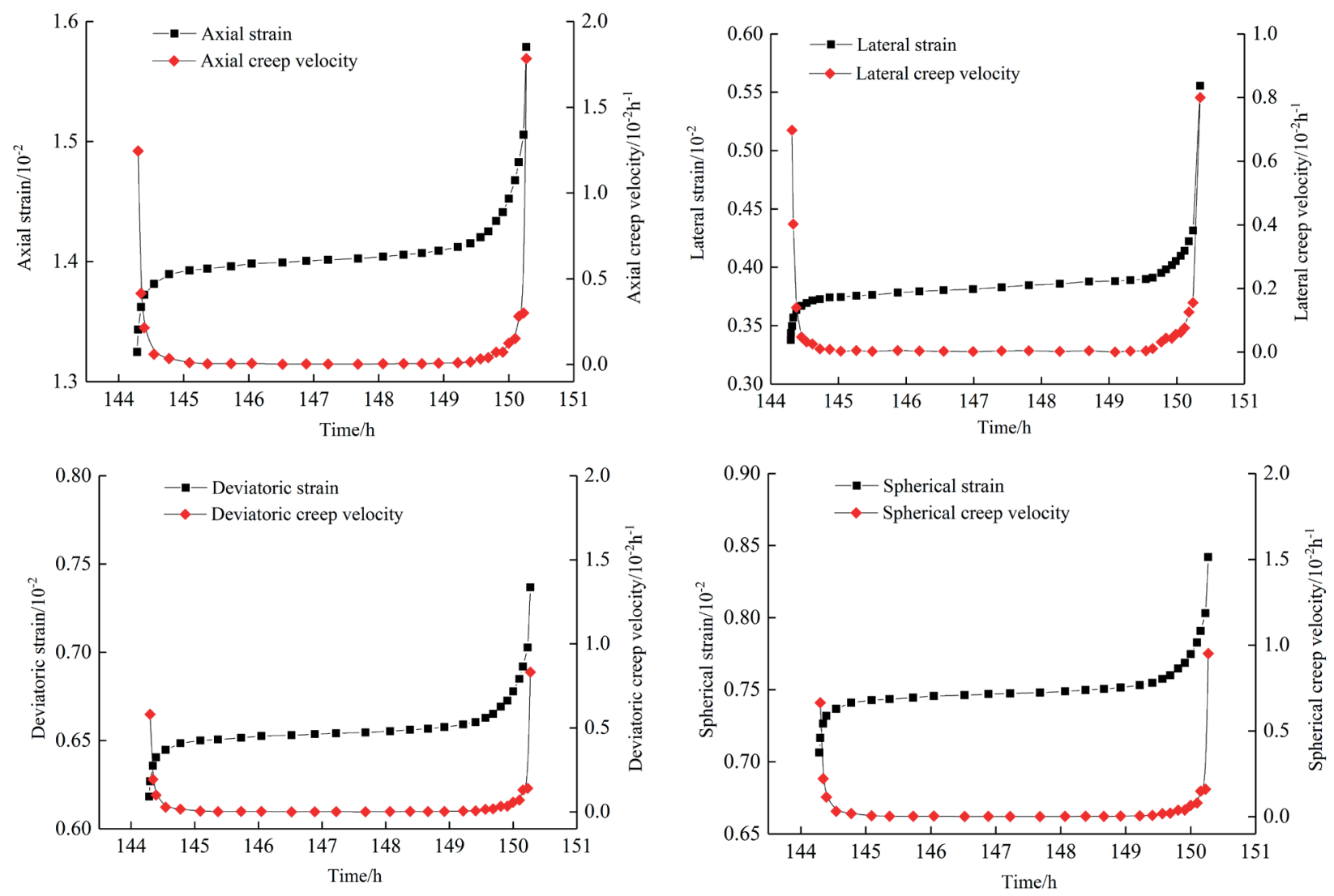

(c)
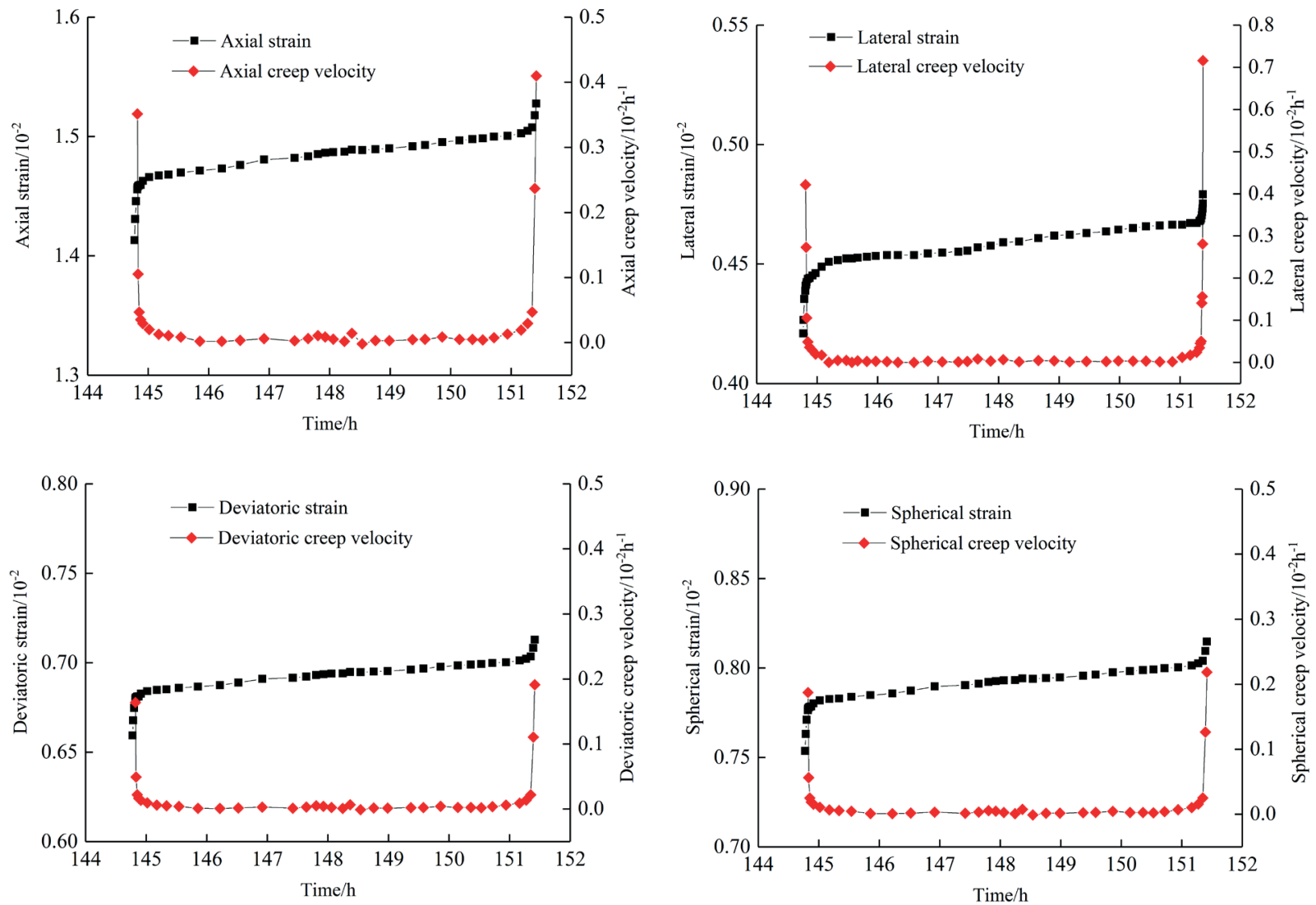

(d) 

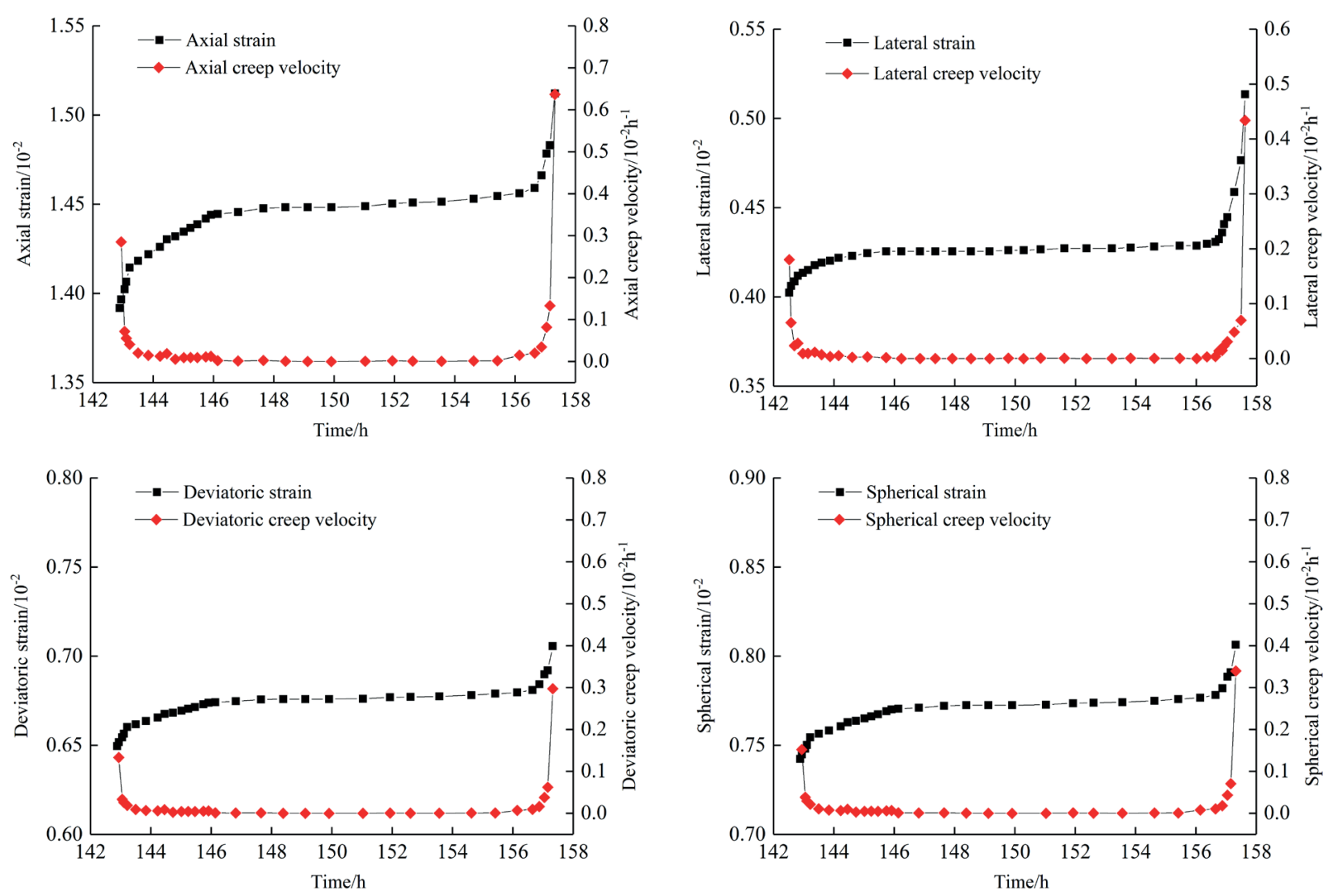

(e)

Fig. 10 Strain and strain rate versus time at different water pressure; (a) $0 \mathrm{MPa}$ water pressure; (b) $0.5 \mathrm{MPa}$ water pressure; (c) $1.0 \mathrm{MPa}$ water pressure; (d) $1.5 \mathrm{MPa}$ water pressure; (e) 2.0 MPa water pressure

Table 2 Statistical summaries of creep durations for different stress levels

\begin{tabular}{|c|c|c|c|c|c|c|c|}
\hline \multirow[b]{2}{*}{$\begin{array}{l}\text { water pressure } \\
/ \mathrm{MPa}\end{array}$} & \multirow[b]{2}{*}{$\begin{array}{c}\text { Total } \\
\text { duration } / \mathrm{h}\end{array}$} & \multicolumn{2}{|c|}{ Attenuation creep } & \multicolumn{2}{|c|}{ Constant creep } & \multicolumn{2}{|c|}{ Accelerated creep } \\
\hline & & Duration $/ \mathrm{h}$ & $\begin{array}{c}\text { Proportion of } \\
\text { total duration } / \%\end{array}$ & Duration $/ \mathrm{h}$ & $\begin{array}{l}\text { Proportion of } \\
\text { total duration } / \%\end{array}$ & Duration $/ \mathrm{h}$ & $\begin{array}{l}\text { Proportion of } \\
\text { total duration } / \%\end{array}$ \\
\hline 0 & 47.86 & 6.20 & 12.95 & 39.19 & 81.88 & 2.47 & 5.16 \\
\hline 0.5 & 16.08 & 2.18 & 13.56 & 12.77 & 79.42 & 1.13 & 7.03 \\
\hline 1.0 & 6.47 & 1.05 & 16.23 & 4.9 & 75.73 & 0.52 & 8.04 \\
\hline 1.5 & 6.52 & 1.18 & 18.10 & 4.69 & 71.93 & 0.65 & 9.97 \\
\hline 2.0 & 14.98 & 3.01 & 20.09 & 10.17 & 67.89 & 1.80 & 12.02 \\
\hline
\end{tabular}

\subsection{Analysis of strength characteristics}

The long-term strength is one of the main parts of creeping and strength index of rock mass, which is significantly lower than instantaneous strength. In this study, the strength of sandstone samples was determined based on isochronous curve method [27].

Summaries of creep failure and long-term strength are shown in Table 3. The creep failure and long-term strength of sandstone versus water pressure are shown in Fig. 11.

A relationship for creep failure strength, long-term strength, and water pressure can be established by the following function $y=y_{0}-a \ln \left(1+p^{b}\right), p$ represents the water pressure.
Table 3 Summaries of creep failure strength and long-term strength

\begin{tabular}{lcc}
\hline water pressure/MPa & $\begin{array}{c}\text { creep failure } \\
\text { strength/MPa }\end{array}$ & $\begin{array}{c}\text { long-term strength/ } \\
\mathrm{MPa}\end{array}$ \\
\hline 0 & 70 & 65 \\
0.5 & 65 & 60 \\
1.0 & 60 & 55 \\
1.5 & 57.5 & 52 \\
2.0 & 55 & 50 \\
\hline
\end{tabular}

Equations (1) and (2) are of the best fitting curve is as follows:

Creep failure strength: 
$\sigma=70-13.67 \ln \left(1+p^{1.03}\right)$.

Long-term strength:

$\sigma=65-13.84 \ln \left(1+p^{1.03}\right)$.

The following points were pointed out based on Table 3 and Fig. 11:

1. The creep failure strength was decreasing gradually while the water pressure increased. At $0 \mathrm{MPa}$ water pressure, the creep failure strength is $70 \mathrm{MPa}$. The creep failure strength of sandstone specimens was $0.5 \mathrm{MPa}$, 1.0 $\mathrm{MPa}, 1.5 \mathrm{MPa}$, and $2.0 \mathrm{MPa}$ at $65 \mathrm{MPa}, 60 \mathrm{MPa}, 57.5 \mathrm{MPa}$, and $55 \mathrm{MPa}$ water pressure, respectively. The creep strength was reduced linearly (Fig. 11).

2. The long-term strength of the sandstone sample was decreasing slowly while the water pressure increased. At $0 \mathrm{MPa}$ water pressure, the long-term strength of the sandstone sample was $64 \mathrm{MPa}$. The creep failure strength of sandstone rock was $60 \mathrm{MPa}, 57 \mathrm{MPa}$, $54 \mathrm{MPa}$, and $50 \mathrm{MPa}$ at $0.5 \mathrm{MPa}, 1.0 \mathrm{MPa}, 1.5 \mathrm{MPa}$, and 2.0 MPa water pressure, respectively. The longterm strength was reduced linearly (Fig. 11).

3. The creep failure strength and long-term strength of the sandstone were decreasing continuously while the water pressure increased, indicating that the increase in the water pressure led to the decrease in the mechanical properties of the sandstone sample.

\subsection{Analysis of creep damage characteristics}

The creep failure modes of sandstone samples with different water pressures were investigated as shown in Fig. 12.

The following points were pointed out based on Fig. 12:

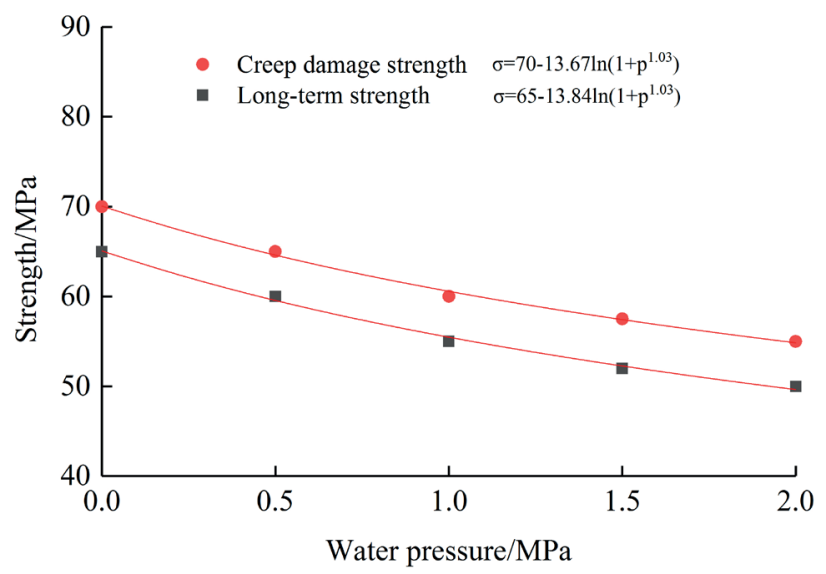

Fig. 11 Long-term strength and creep failure strength versus water pressures

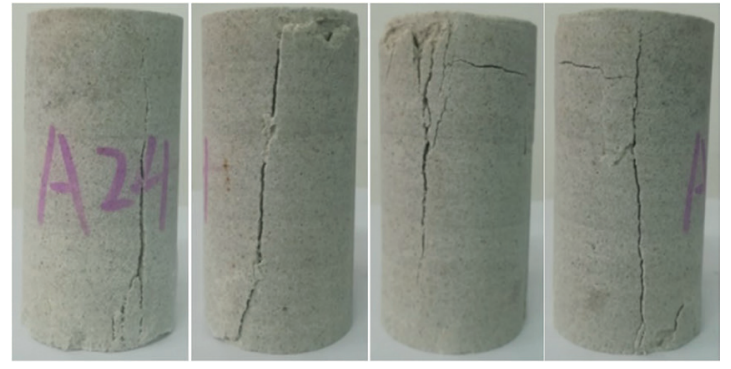

(a)

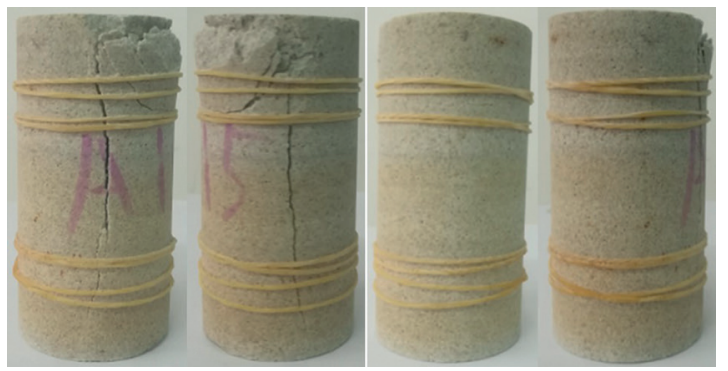

(b)

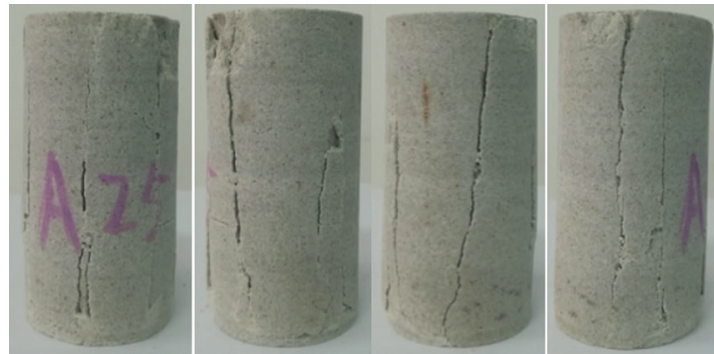

(c)

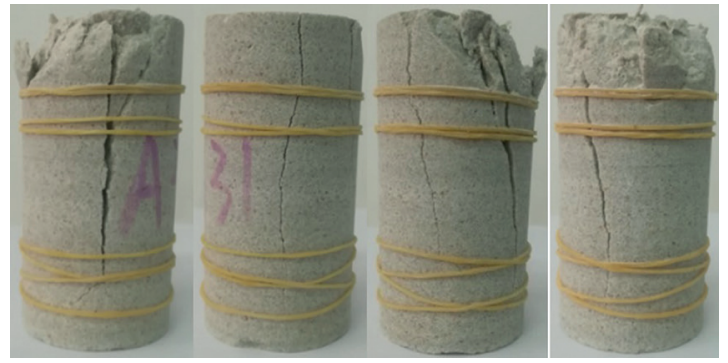

(d)

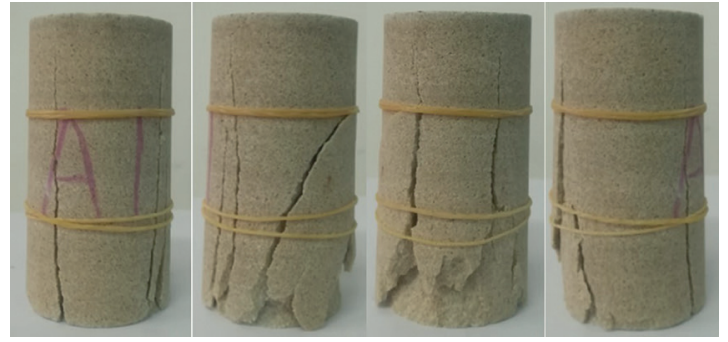

(e)

Fig. 12 Failure modes of sandstone rock at different water pressures; (a) $0 \mathrm{MPa}$ water pressure; (b) $0.5 \mathrm{MPa}$ water pressure; (c) $1.0 \mathrm{MPa}$ water pressure; (d) $1.5 \mathrm{MPa}$ water pressure; (e) $2.0 \mathrm{MPa}$ water pressure 
1. The sandstone samples showed tensile failure characteristics at different water pressures. A conical rupture surface was developed at the tip of the specimens. When creep damage occurs, the crack on the surface of the sample is in the axial direction, which is a typical tensile failure.

2. The extent of fracture was increasing slowly while the water pressure increased. The angle between the main crack and the axial direction increases gradually.
The increase in water pressure leads to a decrease in the mechanical properties of sandstone samples. Under the action of axial load, the lateral deformation of sandstone specimens increases, as a result, axial tensile cracks are developed. The shear deformation yielded internal slippage and shear band of particles. Therefore, the shear bands will join together to form a shear crack.

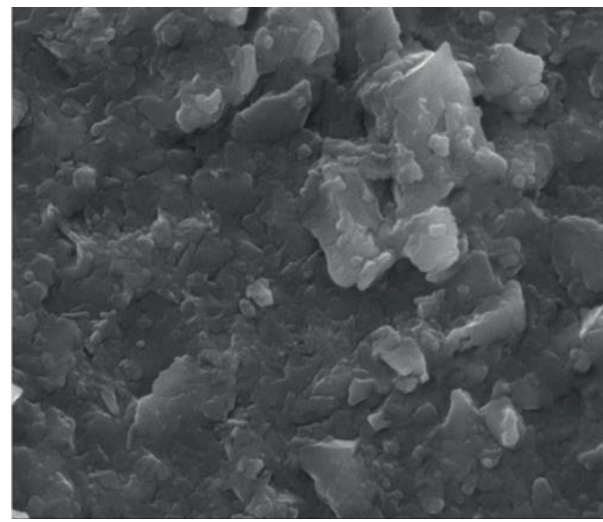

(b)

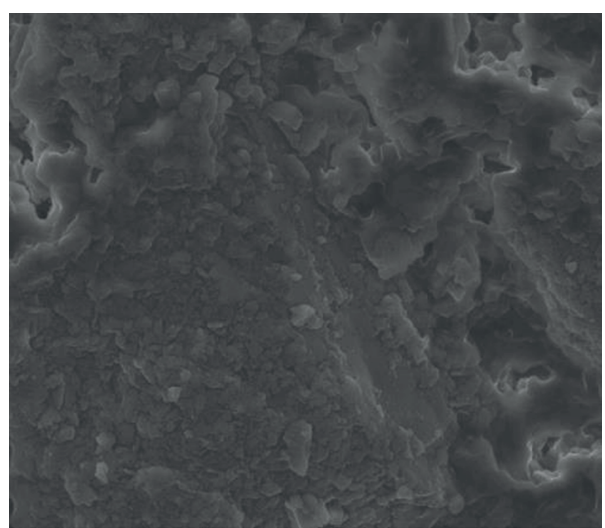

(d)

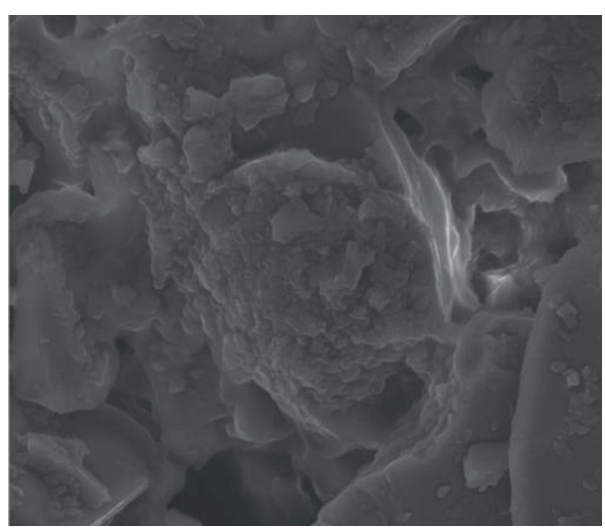

(e)

Fig. 13 Typical rock samples at different water pressures (1200×); (a) 0MPa water pressure; (b) 0.5MPawater pressure; (c) 1.0MPawater pressure; (d) 1.5MPawater pressure; (e) 2.0MPawater pressure 


\subsection{Analysis of microstructural changes at different water pressures}

The change in the microstructure is a result of deterioration in the macroscopic mechanical properties. The electron microscope was used to analyze the microstructural changes. Typical rock samples are shown in Fig. 13 (with 1200x resolution).

As can be seen from Fig. 13:

Sandstone specimens showed significant microstructural changes at different water pressures. With no water pressure, the structure between the particles was tight, and only a few micropores were developed. The particles were getting a weak structure while the water pressure increased. Moreover, thin pores were noticed as a result of water pressure. The particles were scattered due to the propagation of micro-cracks.

A considerable amount of micro-pores were developed inside sandstone specimens. In the conventional test, water plays a softening role on the instantaneous strength. The applied stress is responsible for the reorientation of micro-cracks. The presence of water inside the pores softens the hydrophilic component, resulting, a decrease in the bearing capacity of the rock (increase in the creep). The presence of pore water pressure is responsible for the reduction in the normal effective stress and an increase in the propagation of cracks. The pore water pressure reaches the crack tip in time, forming an "intrusion" effect, which promotes the expansion and penetration of the fracture, thereby reducing the bearing capacity of the rock and accelerating the rock deformation. In addition, the infiltrated water plays a lubricating role, reduce the cohesive force, and increase the slippage and misalignment of the rock skeleton. Therefore, compared with conventional saturated rock, coupled stress-water pressure has a

\section{References}

[1] Dyke, C. G., Dobereiner, L. "Evaluating the strength and deformability of sandstones", Quarterly Journal of Engineering Geology and Hydrogeology, 24(1), pp. 123-134, 1991. https://doi.org/10.1144/GSL.QJEG.1991.024.01.13

[2] Hawkins, A. B., McConnell, B. J. "Sensitivity of sandstone strength and deformability to changesw in moisture content", Quarterly Journal of Engineering Geology and Hydrogeology, 25(2), pp. 115-130, 1992.

https://doi.org/10.1144/gsl.qjeg.1992.025.02.05

[3] Chang, C., Haimson, B. "Effect of fluid pressure on rock compressive failure in a nearly impermeable crystalline rock: Implication on mechanism of borehole breakouts", Engineering Geology, 89(3-4), pp. 230-242, 2007.

https://doi.org/10.1016/j.enggeo.2006.10.006 considerable adverse effect on the rock strength. The presence of water pressure reduces the bearing capacity and long-term creep strength of the sandstone rock.

\section{Conclusions}

The effect of coupled stress-water pressure on the rock mass properties was simulated by using a laboratory test. Based on the experimental results, the following points were pointed out:

1. At the same stress level, the increase in the water pressure is responsible for the increase in the creep strain, duration between decaying and steady-state creep, and rate of steady-state creep, and decrease in the initial creep rate. The increase in the stress level will increase the creep strain, the initial creep rate, and the rate of steady-state creep.

2. The creep failure strength and long-term strength of the sandstone were decreasing continuously while the water pressure increased, indicating that the increase in the water pressure led to the decrease in the mechanical properties of the sandstone sample. The increase in water pressure enhanced pre-mature yield stage.

3. Sandstone specimens showed significant microstructural changes at different water pressures. Compared with the conventional test, the water pressure weakens the rock strength. The presence of water pressure reduces the rock bearing capacity and long-term creep strength.

\section{Acknowledgments}

This work was supported by the National Nature Science foundation of China (No.51439003), National Nature Science foundation of China (No.51679127) and Natural Science Foundation of Hubei Province (2015CFA140).

[4] Vasarhelyi, B. "Some observations regarding the strength and deformability of sandstones in dry and saturated conditions", Bulletin of Engineering Geology and the Environment, 62(3), pp. 245-249, 2003.

https://doi.org/10.1007/s10064-002-0186-x

[5] Vásárhelyi, B. "Statistical Analysis of the Influence of Water Content on the Strength of the Miocene Limestone", Rock Mechanics and Rock Engineering, 38(1), pp. 69-76, 2005. https://doi.org/10.1007/s00603-004-0034-3

[6] Vásárhelyi, B., Ván, P. "Influence of water content on the strength of rock", Engineering Geology, 84(1-2), pp. 70-74, 2006. https://doi.org/10.1016/j.enggeo.2005.11.011 
[7] Liu, J., Feng, X. T., Ding, X. L., Zhou, H. M. "In Situ Tests on Creep Behavior of Rock Mass with Joint or Shearing Zone in Foundation of Large-Scale Hydroelectric Projects", Key Engineering Materials, 261-263, pp. 1097-1102, 2004.

https://doi.org/10.4028/www.scientific.net/KEM.261-263.1097

[8] Xu, H., Hu, B., Tang, H., Chen, J. "Experiment and model research on shear rheological properties of saturated sandstone", Chinese Journal of Rock Mechanics and Engineering, 29, pp. 2775-2781, 2010.

[9] Tang, J., Peng, Z., Wu, Q., Li, Z. "Test study of effect of water on shear characteristic of rock joint", Journal of Central South University (Science and Technology), 45(4), pp. 1232-1236, 2014.

[10] Chigira, M., Oyama, T. "Mechanism and effect of chemical weathering of sedimentary rocks", Developments in Geotechnical Engineering, 84, pp. 267-278, 2000.

https://doi.org/10.1016/S0165-1250(00)80022-X

[11] Sausse, J., Jacquot, E., Fritz, B., Leroy, J., Lespinasse, M. "Evolution of crack permeability during fluid-rock interaction. Example of the Brézouard granite (Vosges, France)", Tectonophysics, 336(1-4), pp. 199-214, 2001.

https://doi.org/10.1016/S0040-1951(01)00102-0

[12] Polak, A., Elsworth, D., Liu, J., Grader, A. S. "Spontaneous switching of permeability changes in a limestone fracture with net dissolution", Water Resources Research, 40(3), Article number: W03502, 2004.

https://doi.org/10.1029/2003wr002717

[13] Feng, X. T., Ding, W. "Experimental study of limestone micro-fracturing under a coupled stress, fluid flow and changing chemical environment", International Journal of Rock Mechanics and Mining Sciences, 44(3), pp. 437-448, 2007.

https://doi.org/10.1016/j.ijrmms.2006.07.012

[14] Fantong, W. Y., Kamtchueng, B. T., Yamaguchi, K., Ueda, A., Issa, Ntchantcho, R., Wirmvem, M. J., Kusakabe, M., Ohba, T., Zhang, J., Aka, F. T., Tanyileke, G., Hell, J. V. "Characteristics of chemical weathering and water-rock interaction in Lake Nyos dam (Cameroon): Implications for vulnerability to failure and re-enforcement", Journal of African Earth Sciences, 101, pp. 42-55, 2015. https://doi.org/10.1016/j.jafrearsci.2014.08.011

[15] Parkin, A. K. "Creep of Rockfill", In: Advances in Rockfill Structures, Springer-Science + Business Media, B. V., Lisbon, Portugal, 1991, pp. 221-237.

[16] Jin, J., Cristescu, N. D. "An elastic/viscoplastic model for transient creep of rock salt", International Journal of Plasticity, 14(1-3), pp. 85-107, 1998.

https://doi.org/10.1016/s0749-6419(97)00042-9
[17] Kenis, I., Urai, J. L., der Zee, W. V. D., Hilgers, C., Sintubin, M. "Rheology of fine-grained siliciclastic rocks in the middle crustevidence from structural and numerical analysis", Earth and Planetary Science Letters, 233(3-4), pp. 351-360, 2005. https://doi.org/10.1016/j.eps1.2005.02.007

[18] Gasc-Barbier, M., Chanchole, S., Bérest, P. "Creep behavior of Bure clayey rock", Applied Clay Science, 26(1-4), pp. 449-458, 2004. https://doi.org/10.1016/j.clay.2003.12.030

[19] Wang, Z. J., Yin, K., Jian, W. X. "Experimental research on creep of incompetent beds in Jurassic red clastic rocks in Wanzhou", Yantu Lixue/Rock and Soil Mechanics, 28, pp. 40-44, 2007.

[20] Xu, W., Zhou, J., Yang, S., Shi, C. "Study on creep damage constitutive relation of green schist specimen", Chinese Journal of Rock Mechanics and Engineering, 25, pp. 3093-3097, 2006. https://doi.org/10.3321/j.issn:1000-6915.2006.z1.077

[21] Yang, S. Q., Xu, W. Y., Yang, S. L. "Investigation on shear rheological mechanical properties of shale in Longtan Hydropower Project", Yantu Lixue/Rock and Soil Mechanics, 28(5), pp. 895-902, 2007.

[22] Shen, R. X., Liu, C. W., Liu, X. "Triaxial rheology characteristics and model of carbonaceous shale in pressure water", Chinese Journal of Geotechnical Engineering, 32(7), pp. 1131-1134, 2010.

[23] Liu, J., Li, P., Qiao, L., Zhu, J. "Experimental research on creep behavior and mechanism of sandstones with hydro-physico-chemical effects", Chinese Journal of Rock Mechanics and Engineering, 27(12), pp. 2540-2550, 2008. https://doi.org/10.3321/j.issn:1000-6915.2008.12.022

[24] Yao, J. "Study on sandstone rheological tests and their factors analysis", PhD Thesis, Chengdu University of Technology, 2015.

[25] Ju, N., Huang, H., Zheng, D., Zhou, X., Zhang, C. "Improved Burgers model for creep characteristics of red bed mudstone considering water content", Rock and Soil Mechanics, 37, pp. 67-74, 2016. https://doi.org/10.16285/j.rsm.2016.S2.008

[26] Deng, H., Li, J. L., Deng, C. J., Wang, L. H., Lu, T. "Analysis of sampling in rock mechanics test and compressive strength prediction methods", Rock and Soil Mechanics, 32(11), pp. 3399-3403, 2011. https://doi.org/10.3969/j.issn.1000-7598.2011.11.032

[27] Sun, J. "Rock rheological mechanics and its advance in engineering applications", Yanshilixue Yu Gongcheng Xuebao/Chinese Journal of Rock Mechanics and Engineering, 26(6), pp. 1081-1106, 2007. 